\title{
Indigenous Peoples and National Self-Image in Australia and New Zealand
}

\author{
Adrien Rodd
}

In the 1970s and 1980s, Australia and New Zealand performed a U-turn in selfidentification by formally embracing cultural diversity. Since then, national identity in both countries has become somewhat uncertain and contentious. Over the past decades, the debate over what it means to be an Australian or a New Zealander in a multi-ethnic, multicultural, globalised society has simmered continuously, and has periodically erupted into national public discussions and disagreements. This article aims at examining the importance which the presence and participation of Indigenous peoples may have on the national self-image held by their non-Indigenous fellow citizens.

\section{Challenging Invisibility in a Homogenous Society}

Until the 1960s and 7os, both countries had a policy of cultural and ethnic homogenisation, whereby society should be uniformly "British" - a "monoculture, where everyone lives the same way," as Australian Immigration Minister Billy Snedden put it approvingly in $1969 .{ }^{1}$ This implied racially restrictive immigration policies, which of course could not apply to the Indigenous population. Indigenous Australians (Aboriginals and Torres Strait Islanders ${ }^{2}$ ) were, depending on the colour of their skin and whether they had any white ancestry, either subjected to exclusion and segregation, confined to reserves, or subjected to a self-defeating policy which combined an attempt at forced assimilation with continued discrimination. In New Zealand, by contrast, there was no deliberate policy of exclusion; efforts were made early on to draw Maori into colonial society, where they might expect to be treated almost as equals - so long as they were willing to assimilate and become culturally British. In both countries, the clear and explicit aim was for Indigenous peoples to be rendered "invisible," either through rejection or through a form of cultural and even "biological" assimilation.

1 Quoted in John Rickard, Australia: A Cultural History (London: Longman, 988), 227.

2 Torres Strait Islanders inhabit the islands between Queensland and Papua New Guinea, and are culturally distinct from Aboriginals.

(C) ADRIEN RODD, 2015 | DOI 10.1163/9789004282087_006

This is an open access chapter distributed under the terms of the prevailing CC-BY-NC License at the time of publication. 
Aboriginals were not invited to integrate into colonial society. The very nature of colonial expansion was to seize their lands without compensation, forcibly expel the "natives" further into the interior, and de facto sentence them to starvation, when they were not decimated by diseases or simply murdered by settlers. They were not perceived, even hypothetically, as "fellow Australians." Indeed, legally they were not Australian; they were denied civil liberties and political rights. Section 127 of the Constitution of 1900, repealed in 1967 , provided that they were not to be counted in the census. ${ }^{3}$ Aboriginal peoples made a conscious effort to maintain their traditions, customary practices and values, ${ }^{4}$ but were faced with forced disconnection from the lands in which those traditions were grounded, in addition to often catastrophic demographic decline. ${ }^{5}$

The "White Australia" policy, formally adopted at the time of federation in 1901, considered that the very existence of Aboriginals was a problem to be resolved. So-called "full-bloods" were - it was thought - too primitive to be assimilated, and doing so in any case was not deemed desirable, since it would have invited a black population into white society. Thus they were confined to reserves, where it was assumed they would eventually die out and disappear. The "problem" was the existence of so-called "half-caste" children, the illegitimate offspring of white fathers and black mothers in the bush or the Outback, unrecognised by their fathers and raised in Indigenous communities. From the late 19th century, these children were routinely seized, by force, to be placed on mission stations or adopted into white families. The 1937 federal Conference on Aboriginal Welfare harmonised this policy, and clearly set out its objective: "[T] he destiny of the natives of Aboriginal origin, but not of full blood, lies in their ultimate absorption by the people of [Australia]." ${ }^{6} \mathrm{Or}$, in the words of Cecil Cook, the Protector of Aborigines in the Northern Territory ten years earlier: "The problem of our half-castes will quickly be eliminated by the complete disappearance of the black race, and the swift submergence of their progeny

3 The rationale was that their presence should have no bearing on the number of seats allocated to each state in the federal House of Representatives.

4 Select Committee on the Aborigines and the Protectorate, New South Wales Legislative Assembly Votes and Proceedings (1849), 25.

5 Henry Reynolds, The Other Side of the Frontier: Aboriginal resistance to the European invasion of Australia (Sydney: University of New South Wales Press, 2006 [1981]), 130.

6 Aboriginal Welfare, Initial Conference of Commonwealth and State Aboriginal Authorities (Canberra: Government Printer, 1937), 3. 
in the white."7 Aboriginals were, very explicitly, to be made to disappear. A.O. Neville, the Protector of Aborigines in Western Australia, put it perhaps most clearly of all in 1937, during the conference: "Are we going to have a population of 1,000,00o blacks..., or are we going to merge them into our white community and eventually forget that there were ever any aborigines in Australia?"8

This eugenics policy on a wide scale did not succeed in 'eradicating' Aboriginals. It did, however, cause widespread suffering. Officials were told to pay no attention to the "unfortunate" feelings of mothers whose children they were seizing. ${ }^{9}$ Siblings were deliberately separated. ${ }^{10}$ The children, later to be known as the "Stolen Generations," were not assimilated into white society: they continued to be subjected to racial discrimination and segregation, lacking access to education or employment, except in the most menial tasks. ${ }^{11}$ They were, however, very efficiently cut off from their own people, losing all knowledge of their own language, land and identity.

By contrast, Maori were British subjects, under article 3 of the Treaty of Waitangi of 1840, whereby Maori chiefs had ceded sovereignty to the British Crown. ${ }^{12}$ Although the Treaty was soon discarded by the colonial authorities, the Native Rights Act of 1865 reaffirmed that the Maori were British, with equal rights and duties to those of the settlers. They "benefited" (so to speak) from favourable racial stereotypes. Due to their physical appearance and customs, they were deemed to be "quasi-white" and "quasi-civilised," which meant that they could and should be assimilated easily enough into a white society. ${ }^{13}$ The words of New Zealand's first Governor, William Hobson, were interpreted as a promise of assimilation: "Hi iwi tahi tatou" ("We are one single people"). ${ }^{14}$ In 1867, all Maori men were granted the right to elect a small number of representatives

Cecil Cook, 1927, quoted in David Hollinsworth, Race and Racism in Australia (Katoomba: Social Science Press, 1998), 39.

8 Auber O. Neville, in Aboriginal Welfare, 11.

9 Aborigines Department of Western Australia, Report for Financial Year ending 3oth June 1902 (1902), 3.

$10 \quad$ Phillip Knightley, Australia: a biography of a nation (London: Vintage, 2001), 116.

11 James Jupp, From White Australia to Woomera (Cambridge: Cambridge University Press, 2002), 22.

12 Or were presumed to have ceded it. The interpretation of the Maori language version of the Treaty remains a matter of debate.

13 George W. Rusden, History of New Zealand (Melbourne: Chapman \& Hall, Ltd, 1883), 350.

14 Philippa Mein Smith, A Concise History of New Zealand (Cambridge: Cambridge University Press, 2005), 47. 
to the colonial parliament, ${ }^{15}$ a right which was extended to women in 1893 . Maori MPs soon played an active part in colonial politics. Indigenous New Zealanders were also encouraged to join the civil service. By the very end of the 19th century, they were beginning to graduate from universities, in small numbers, and to become lawyers, doctors or government ministers.

While in Australia there was a mixed policy of exclusion of "full-bloods" and "assimilation" of "half-castes," in New Zealand the marriage of whites and Maori was viewed positively. The aim was similar: biological absorption, with the ultimate expectation that the Maori as such would disappear. As William Herries, Minister for Native Affairs, put it in the 1910s: "I look forward for the next hundred years or so, to a time when we shall have no Maoris at all, but a white race with a slight dash of the finest coloured race in the world."16 He could not have been more explicit.

Broadly speaking, however, there was no widespread assimilation at that time. The vast majority of Maori continued to live a rural lifestyle grounded in traditional practices, and to speak their own language; most white New Zealanders, indeed, had fairly little daily interaction with their Indigenous fellow subjects. ${ }^{17}$ If Maori were "invisible," it was not because they had been culturally or biologically absorbed, but rather because most of them still kept to themselves.

Maori, however, had legitimate grievances, just as Aboriginals had. Maori lands were sometimes seized by force; more commonly, tribes were forced to sell land, through a combination of deceit, legal obligations and outright bullying. Maori politicians campaigned on the issue, leading to some limited restitutions or compensation in the 1920s. Similarly, there was a gradual recognition that Maori people did not wish to "disappear." Gordon Coates, who became Conservative ${ }^{18}$ Prime Minister in 1925 , had grown up in proximity to Maori communities, interacting with them far more than most white people in his day. His friend Apirana Ngata, arguably the most prominent Maori politician of the time, became his informal adviser on Indigenous policy, despite sitting

15 Since 1976, Maori have had the option to register on the general electoral roll, rather than register in a Maori constituency. (Following the 2011 general election, 19 per cent of MPS are Maori, mostly representing general constituencies, while Maori constitute about 14 per cent of the population. By contrast, there is one Aboriginal member (i.e., 0.4 per cent) in the Australian federal Parliament following the 2010 election, while Indigenous Australians constitute about 2.5 per cent of the population).

16 William Herries, quoted in James Belich, Paradise Reforged:A History of the New Zealanders from the 1880s to the Year 2000 (Honolulu: University of Hawai'i Press, 2001), 190.

17 Belich, Paradise Reforged, 466.

18 Reform Party. 
on the opposition benches. While pursuing a policy of overall assimilation, Coates actively encouraged Maori arts and crafts production, ${ }^{19}$ which was viewed as safely compatible with close-knit integration. The idea was emerging that a remnant of Maori culture provided New Zealand with an attractive particularity. Indeed, postcards at the time depicted New Zealand as "Maoriland," where British-looking landscapes and towns coexisted with the unique "exoticism" of an Indigenous presence. ${ }^{20}$ Maori art, particularly sculpture, had been admired by whites ever since first contact, and perceived as a sign of Maori civilisation. In the 1930s, Maori voters began to favour politicians of the Ratana movement, which, for the first time, rejected the idea of cultural absorption, and advocated a distinctive, renewed and unified, pan-tribal Maori cultural identity. Ratana found an ally in New Zealand's first Labour Prime Minister, Michael Savage (1935-1940), who set about improving Maori access to education and economic opportunities, provided them with equal rights to welfare, but also expressed support for the maintaining of a distinct Maori identity. ${ }^{21}$ In 1960, in response to the increased urbanisation of Maori, the official policy, as outlined in the Hunn Report, was to "combine (not fuse) the Maori and Pakeha ${ }^{22}$ elements to form one nation wherein Maori culture remains distinct." 23 The phrasing sounded promising; in practice, however, the expectation was still that Maori would assimilate as much as possible into a "British" way of live, while white New Zealanders of course were not expected to adopt Maori practices or values. Protest movements in the 196os highlighted grievances over the continued seizing of lands, and emphasised Indigenous rights under the Treaty of Waitangi, ${ }^{24}$ making the Maori inescapably visible.

In Australia, meanwhile, Aboriginal protest movements had begun in the 1920s, petitioning for a restitution of stolen children and lands, an end to segregation and discrimination, freedom of movement in and out of the reserves,

19 Michael King, "Between Two Worlds," in The Oxford History of New Zealand, ed. W.H. Oliver (Oxford: Clarendon Press, 1981), 291.

20 James Belich, "European ideas about Maori - The Aryan Maori and other stereotypes," in Te Ara - the Encyclopedia of New Zealand. <http://www.teara.govt.nz>, New Zealand Ministry for Culture and Heritage, visited on 15 November 2012.

21 Roger C. Thompson, "Britain, Germany, Australia, and New Zealand in Polynesia," in Tides of History: The Pacific Islands in the Twentieth Century, K.R. Howe, Robert Kiste and Brij Lal (Honolulu: University of Hawai'i Press, 1994), 87.

22 I.e. non-Indigenous. In practice, the word generally applies only to white New Zealanders, and usually specifically to those of British descent.

23 J.K. Hunn, Report on Department of Maori Affairs with Statistical Supplement (24 August $1960), 14-15$.

24 Mein Smith, A Concise History of New Zealand, 227-229. 
equal rights in terms of access to education and employment, and equal political rights. Inspired by the example of New Zealand, they asked for the right to be represented in government. ${ }^{25}$ The petitions were routinely turned down. Prominent among the movements was William Cooper's Australian Aborigines League, in the 1930 s. $^{26}$ At this stage, Aboriginals did not claim the right to cultural difference. They demanded that which was most urgent: the right to be considered Australian, and to be granted the most basic of human and civil rights. Or, to put it another way, the right to integrate into colonial society, now that their own way of life had been shattered and had become untenable.

Civil rights campaigns by Indigenous Australians and their non-Indigenous supporters, reaching the public through media coverage, led to their obtaining the right to vote in federal elections ${ }^{27}$ in 1962 , followed - logically enough - by their being counted in the census from 1967. In the early 1970s, the removal of children finally ceased. In 1975, under Labor Prime Minister Gough Whitlam, the Racial Discrimination Act outlawed all forms of racial discrimination, following New Zealand's Race Relations Act of $1971 .{ }^{28}$ There were sporadic cases of land restitutions in Australia over the following years, but as this was seen as a state issue rather than a federal one, progress was slow. The concept of native title was not recognised in law until the High Court case Mabov Queensland in 1992, followed by the Native Title Act 1993. Native title, however, is considered to be extinguished wherever Aboriginals have not been able to maintain a continuous presence on the land.

\section{Constructing Identity in a Multicultural/Globalised Society}

\section{Promoting Indigenous Identity}

The very concept of indigeneity is, of course, a product of the encounter with colonisers, and subsequent marginalisation in relation to the settler majority. Prior to such contact, Aboriginals did not have a collective name for themselves, and neither did Maori; their identity was grounded in tribes or clans,

25 Petition of the Aboriginal Inhabitants of Australia to His Majesty, George V, etc..., (1933), quoted in Bain Attwood and Andrew Markus, Thinking Black: William Cooper and the Australian Aborigines League (Canberra: Aboriginal Studies Press, 2004), 35-36.

26 Kate Cameron, "Aboriginal struggle for citizenship," Australian Broadcasting Corporation, 2000. <http://www.abc.net.au/civics/democracy/struggle.htm>, visited on 26 June 2013.

27 In 1965, Queensland was the last state to grant Indigenous people the right to vote at state level.

28 Under Conservative Prime Minister Keith Holyoake (National Party). 
common descent, a spiritual connection with a particular area of land (particularly in Australia) and, for Aboriginals, language. The collective name "Aboriginal" was imposed from the outside, and it was not until the 1920 s that different Aboriginal peoples used it to claim common interests and common grievances. In New Zealand, the very earliest settlers viewed themselves solely as British, and described the Indigenous tribes as "New Zealanders." By the 1830s, settlers had, however, claimed that name for themselves as they envisaged their future in the colony, while the first peoples of the land now called themselves tangata maori - which means "normal people." 29 They recognised the settlers as human beings, but of an 'abnormal' sort; this differentiation laid the grounds for a collective sense of Indigenous self-identification. Gradually, pan-tribal movements sought to build on a common identity, albeit without negating the importance of tribal belonging. In Australia, as languages and cultures were erased, and the vital connection to the land was broken, denying people the very essence of their specific identity, ethnicity and the Aboriginal "label" became an obvious basis for a reconstructed identity, and for more effective collective demands. Hence the notions of Aboriginality and Maoritanga ${ }^{30}$ which came to be defined gradually, in the 2oth century, around elements of cultural identity, perceived to be shared rather than grounded in any particular tribe or clan.

In the 1970s, the state in both countries quietly abandoned its assimilationist policies. ${ }^{31}$ It was now accepted that Indigenous people, as citizens, could participate in society, without fully subscribing to the monoculture which, until then, had formed the basis of these countries' national identities. Crucially, and inevitably, Maoritanga and Aboriginality were constructed in large part through a process of differentiation from society's dominant and mostly British culture or values, or way of life. To be Indigenous, then, was to do things differently from the descendants of settlers, by recalling and preserving pre-colonial practices, and to want to continue doing so. Consequently, the nation now had to perceive itself as a union comprising majority and minority cultures defined through self-differentiation.

More generally, it is in the 1970 s and 8os that both countries opened up to globalisation, and their national identities became far more complex, uncertain

29 James Belich, Making Peoples: A History of the New Zealanders from Polynesian Settlement to the End of the Nineteenth Century (Honolulu: University of Hawai'i Press, 1996), 233-234.

$30 \quad$ The suffix - tanga can be loosely translated as "that which refers to."

31 Graeme Dunstall, "The Social Pattern," in Oliver, W.H., The Oxford History of New Zealand, 426. 
and contentious. Ever since the colonial era, they had largely isolated themselves from the rest of the world, focusing on their tight-knit relationship with the "mother country," relying on the United States for defence, and turning their backs on the Asia-Pacific region in particular. ${ }^{32}$ Restrictive, racist immigration policies were gradually dismantled from the 196os, ending the oftenaffirmed idea that national unity required racial homogeneity. In 1973, to the dismay of many Australians and New Zealanders, the United Kingdom joined the European Economic Community, and in so doing turned its back in turn on the Commonwealth. Not only did this mean the end of Commonwealth trading privileges, but New Zealanders and Australians were curtly informed that they would no longer be considered British nationals when visiting the "home country." ${ }^{33}$ Rejected by the 'motherland', they had not only to diversify their foreign trade, but to rethink their place in the world, and the very notion of who they were. If not British, then what?

In the 1970s, as non-white immigrants were seen on the streets of Australia, Labor Prime Minister Gough Whitlam began to talk of "multiculturalism," a new national identity for this new and changing era. Immigrants would no longer be required to assimilate into a British way of life. ${ }^{34}$ Whitlam's successors in the 1980 s promoted and encouraged cultural diversity as an asset for a vibrant and modern, post-British nation. The promotion of cultural diversity, it was said, would facilitate social cohesion, by making cultural minorities feel welcome and accepted, thus making them feel Australian. ${ }^{35}$ The nation's museums and art galleries, as well as the state media, were encouraged to "reflect Australia's cultural diversity." 36 This naturally included expressing the value of Indigenous cultures. But the main Indigenous issue, first broached by Labor Prime Minister Bob Hawke in 1991, was that of reconciliation. ${ }^{37}$ In 1992, his successor Paul Keating gave what is arguably the most significant speech in Australian history, in Redfern, the predominantly Aboriginal quarter of Sydney:

32 New Zealand's micro-imperialist endeavours in Polynesia, exercising control over remote small island territories in the name of the British Crown, constitute only a partial exception.

33 Knightley, Australia: a biography of a nation, 302.

34 Al Grassby, A Multi-Cultural Society for the Future (Canberra: Australian Government Publishing Service, 1973), 2-3.

35 Australian Ethnic Affairs Council, Australia as a Multicultural Society (Canberra: government press, 1977), 7 .

36 Jupp, From White Australia to Woomera, 5 .

37 Bain Attwood and Andrew Markus, The Struggle for Aboriginal Rights (Sydney: Allen \& Unwin, 1999), 24. 
[C]omplex as our contemporary identity is, it cannot be separated from Aboriginal Australia...It begins, I think, with the act of recognition. Recognition that it was we who did the dispossessing. We took the traditional lands and smashed the traditional way of life. We brought the disasters. The alcohol. We committed the murders. We took the children from their mothers. We practised discrimination and exclusion... ${ }^{38}$

Reconciliation was expressed as the necessary precondition to building a shared, harmonious society, grounded in a common identity as fellow Australians. National Sorry days at the end of the century enabled more than a million ordinary Australian people to express their grief and regret over the Stolen Generations, through marches or through widely circulated "Sorry books"39; this was followed by a formal apology by the government and Parliament in 2008 .

Meanwhile, however, the Hawke government in the 1980 s had continued Australia's embrace of globalisation by dismantling protectionist barriers and liberalising the economy, diminishing the welfare state which had been a cornerstone of Australian society. New Zealand's Labour government adopted similar policies at the same time, under David Lange. Australia and New Zealand were opened up to the world's goods and migrants, with enthusiasm on the part of their respective Labour governments, but far less so on the part of many ordinary people. The reclusive, racist, protectionist, paternalist monoculture had given way to an age of diversity - and, almost inevitably, of concern, questions and uncertainty.

In 1975, Bill Rowling's Labour government in New Zealand set up the Waitangi Tribunal. Its task was to offer recommendations as to how the authorities should respect and uphold the "principles of the Treaty" 40 - a novel concept. One of these principles was to be the preservation of Maori taonga - a word featuring in article 2 of the Maori language version of the Treaty of Waitangi, and retroactively interpreted as meaning "cultural treasures." In 1987, the Court of Appeal found respect for the Treaty's principles to be a legal obligation for public authorities..$^{41}$ Thus, it was incumbent upon the state to ensure the survival, continuation and enhancement of Indigenous culture. As a consequence, the Maori language became an official national language of

38 Paul Keating, "Redfern Park Speech," 10 December 1992; full text: Indigenous Law Bulletin, vol.5, n ${ }^{\circ}$ (2001). <http://www.austlii.edu.au/au/journals/ILB/2001/57.html>, visited on 26 June 2013.

Knightley, Australia: a biography of a nation, 332.

40 Treaty of Waitangi Act, preamble.

41 New Zealand Court of Appeal, New Zealand Māori Councilv. Attorney-General (1987). 
New Zealand, alongside English. ${ }^{42}$ Preschools in which the Maori language was used exclusively, so as to revitalise it within a new generation, had initially been set up as private initiatives; they now received government funding and support. Public funding was dedicated to the renovating of marae, tribal or pan-tribal community centres. ${ }^{43}$ On a more symbolic level, in the 1980 s the nation was redefined, in bipartisan public discourse, as a bicultural partnership between Pakeha and Maori, grounded in the Treaty of Waitangi, which was celebrated as the nation's "founding document." ${ }^{4}$

\section{Being "Non-Indigenous," and the National Self-Image}

It was in this context that the national image had to be rethought in such a way as to integrate Indigenous cultures. Broadly speaking, the "cultural content" of Indigenous identity was seen as fairly clear, even if it subsumed local differences under the blanket image of a national Indigenous culture. For instance, the didgeridoo ${ }^{45}$ is specific to northern and central Australia, and Indigenous dot art developed in Australia's central deserts, but these elements are widely perceived as "Aboriginal culture," and by extension as a unique, valued and instantly recognisable aspect of Australian culture. Thus they are represented on postcards and souvenirs, a cultural package to export a memorable image of the country. Similarly, the haka, performed by All Blacks of all ethnic backgrounds, arguably provides a far more famous and striking cultural image of New Zealand than anything produced by the country's non-Indigenous people. And greenstone tiki pendants, small Maori carvings of strangely warped figures, are perhaps the most iconic product to be sold to tourists.

In addition to what might be seen as a form of easy commercial objectification, Indigenous authors have given their own voice to representations of contemporary society. Most famously in New Zealand, Whiti Ihimaera's novel Whale Rider depicts a young Maori generation's simultaneous upholding and modernising of tradition, while Alan Duff's Once Were Warriors casts a grim light on urban Maori gangs who have abandoned the essence of their culture in favour of one that is rootless, warped, violent, but not entirely hopeless. Both of these novels reached an international audience when they were made into films, in 2002 and 1994 respectively. ${ }^{46}$ Some of the world's most prominent

\footnotetext{
42 Mãori Language Act (1987).

43 Michael King, The Penguin History of New Zealand (Auckland: Penguin Books, 2003), 486.

44 Douglas Graham, "Crown Proposals for the Settlement of Treaty of Waitangi Claims: Summary," (Wellington: Office of Treaty Settlements, 1996), 1.

45 The didgeridoo is a wind instrument made from a long hollowed-out branch.

46 The film version of Once Were Warriors was itself directed by a Maori filmmaker, Lee Tamahori.
} 
images of New Zealand were thus mediated through an Indigenous focus and perspective. In Australia, Indigenous writers have not achieved such international prominence, although Sally Morgan's autobiographical exploration of Aboriginality has been read by many non-Indigenous Australians, ${ }^{47}$ and Aboriginal authors such as Jack Davis or Kevin Gilbert have produced plays, poems or novels depicting Indigenous struggles and disorientation, compensated by a tentative or fierce pride in one's cultural roots. More significantly in terms of effective imagery, the recent film Australia, which was intentionally and explicitly marketed globally to attract tourists to the country, ${ }^{48}$ offered scenes of Aboriginal mysticism and endurance in the Outback, depicted as the heart and source of the country's identity.

This national appropriation of Indigenous art or imagery, and the more personal works of Indigenous writers and artists, have partly addressed the uncertainty prevalent at the heart of national identity since the profound social and economic changes of the 1970s and 8os, and since the hurtful 1970s rejection by the "motherland." But in these recently opened, recently globalised societies, in which the expression of minority cultural identities is actively promoted by successive governments, a recurring question over the last decades has been what it might mean to be an Australian or a New Zealander without having a meaningful, personal connection to Indigenous culture, or indeed to any immigrant minority culture.

This was seen perhaps most strikingly when, in 1998 and 2001, New Zealand and Australia respectively opened a national museum, set up as a government initiative to depict the country's national identity, its unity in diversity. The Museum of New Zealand Te Papa Tongarewa,49 in Wellington, has broadly been seen as a success, but it has also raised questions and controversies. Among its primary aims was to represent the country's biculturalism. But while representing Maori culture posed no great difficulty, the concrete representation of Pakeha ${ }^{50}$ culture and identity was inherently problematic. The decision to depict a modern, consumerist way of life, rather than a "culture" in the more noble sense, was criticised. ${ }^{51}$ Australia's National Museum in

47 Sally Morgan, My Place (Fremantle: Fremantle Press, 2010 [1987]).

48 Elizabeth Gosch, "See the film, then come visit," in The Australian, June 16, 2008. <http:// www.theaustralian.com.au/news/see-the-film-then-come-visit/story-e 6 frgcs 6 -1111116642284>, visited on 26 June 2013 .

49 Literally, 'the place of this country's treasures'.

50 See note 22.

51 Michael Goldsmith, "'Our Place' in New Zealand Culture: How the Museum of New Zealand Constructs Biculturalism," in Ethnologies comparées 6 (2003). <http://recherche .univ-montp3.fr/cerce/r6/m.g.s.htm>, visited on 26 June 2013. 
Canberra, which depicted the "Australian Way of Life" through the everyday consumer objects of suburban materialist comfort, while devoting other sections to a respectful representation of Indigenous culture, faced similar criticism, particularly from the right. But it was in New Zealand that the issue was most pressing from a non-Indigenous perspective. If the nation was now to be imagined as a partnership of two distinct but united cultural communities, the Maori and the Pakeha, then the question of "Pakeha culture" had to be raised. What did it mean to be a Pakeha, as distinct from being simply a New Zealander? The question might conceivably seem artificial, but it was inherent in the new official definition of the nation, and it was grappled with - all the more so as the National Museum had highlighted the question rather than offer a fully satisfactory answer. It touched, of course, upon the issue of national specificity in a globalised world.

New Zealand's most prominent historian, James Belich, refers to it as a Pakeha "identity crisis." He argues that minority communities can identify with, and claim, a fairly clear cultural identity, whereas Pakeha - loosely defined as the descendants of British settlers - cannot. ${ }^{52}$ Sociologist Claudia Bell suggests that "[t]he Maori cultural renaissance has led Pakeha to respond by taking a closer look at who we are." ${ }^{53}$ She refers to cultural representation days in schools, during which children of Maori, East Asian, southern European or Pacific Islander background are able to demonstrate elements - such as clothing or songs and "traditional dances"- which supposedly epitomise their culture, whereas Pakeha children are left to simulate a rugby match, for instance. Bell comments that this implies ethnic minorities have culture while Pakeha have only sport ${ }^{54}$; to go further, one could remark that the Pakeha children are acting out an element of national identity, rather than one specific to any community. In other words, Pakeha identity appears indistinguishable from the wider nation (Maori included), which in turn appears to lack any clear cultural content.

In 1999, historian Michael King published a book entitled Being Pakeha Now, in which he identified as a "white native," and explained:

To be Pakeha on the cusp of the twenty-first century is not to be European; it is not to be an alien or a stranger in my own country. It is to be a nonMaori New Zealander who is aware of and proud of my antecedents, but

\footnotetext{
$5^{2}$ Belich, Paradise Reforged, 465.

53 Claudia Bell, Inventing New Zealand: Everyday Myths of Pakeha Identity (Auckland: Penguin, 1996), 1.

54 Bell, Inventing New Zealand, 88-89.
} 
who identifies as intimately with this land, as intensively and as strongly, as anybody Maori. ${ }^{55}$

This is perhaps as close as anyone has come to resolving the conundrum. It posits a continued distinction between Maori and Pakeha, thus preserving the foundational notion of biculturalism, while simultaneously affirming that both peoples together constitute one people, through their common attachment to their country, their land, their shared way of life and the myriad cultural references that Maori and Pakeha share, and which distinguish them from foreigners.

Globalisation came suddenly to New Zealand and Australia, when, largely by necessity, they opened up to the world's migrants and commerce, at the same time as they were forced, through London's unilateral dismantling of the "British world," to construct new, post-British national identities for themselves. Within this context, Aboriginal and Maori cultures, being uniquely grounded in their respective countries, were promoted as a key part of a widely shared national image. ${ }^{56}$ Nonetheless, as cultures from around the world are also celebrated as those of minority communities, both countries have entered a persistent period of uncertainty, nagged by an endlessly repeated question: What common identity can, and should, be promoted to bind together the people of a globalised society?

\section{Bibliography}

Attwood, Bain and Andrew Markus. The Struggle for Aboriginal Rights. Sydney: Allen \& Unwin, 1999.

Attwood, Bain and Andrew Markus. Thinking Black: William Cooper and the Australian Aborigines League. Canberra: Aboriginal Studies Press, 2004.

55 Michael King, Being Pakeha Now (Auckland: Penguin, 1999), 239.

$5^{6}$ The latest example of this came in February 2013, when the Australian Parliament adopted, on a bipartisan basis, a bill formally recognising Aboriginals and Torres Strait Islanders as the nation's first peoples. Aden Ridgeway, an Aboriginal and former federal Senator, responded to the passing of the bill by commenting that Australia's pre-colonial Aboriginal history 'connects every Australian today - black or white- with the oldest living culture in human history'. He also referred to the New Zealand model, where he said non-Indigenous people view Maori culture as part of their own. $C f$. Aden Ridgeway, "Constitution needs to include Australia's first chapter," Sydney Morning Herald, February 14, 2013. <http://www.smh.com.au/opinion/politics/constitution-needs-to-include -australias-first-chapter-20130213-2edaz.html>, visited on 26 June 2013. 
Belich, James. Making Peoples: A History of the New Zealanders from Polynesian Settlement to the End of the Nineteenth Century. Honolulu: University of Hawai'i Press, 1996.

Belich, James. Paradise Reforged: A History of the New Zealanders from the 1880 s to the Year 200o. Honolulu: University of Hawai'i Press, 2001.

Bell, Claudia. Inventing New Zealand: Everyday Myths of Pakeha Identity. Auckland: Penguin, 1996.

Grassby, Al. A Multi-Cultural Society for the Future. Canberra: Australian Government Publishing Service, 1973.

Hollinsworth, David. Race and Racism in Australia. Katoomba: Social Science Press, 1998.

Jupp, James. From White Australia to Woomera. Cambridge: Cambridge University Press, 2002.

King, Michael. Being Pakeha Now. Auckland: Penguin, 1999.

King, Michael. The Penguin History of New Zealand. Auckland: Penguin Books, 2003. Knightley, Phillip. Australia: a biography of a nation. London: Vintage, 2001.

Mein Smith, Philippa. A Concise History of New Zealand. Cambridge: Cambridge University Press, 2005.

Morgan, Sally. My Place. Fremantle: Fremantle Press, 2010 [1987].

Oliver, W.H., ed. The Oxford History of New Zealand. Oxford: Clarendon Press, 1981.

Reynolds, Henry. The Other Side of the Frontier: Aboriginal Resistance to the European Invasion of Australia. Sydney: University of New South Wales Press, 2006 [1981].

Rickard, John. Australia: A Cultural History. London: Longman, 1988.

Rusden, George W. History of New Zealand. Melbourne: Chapman \& Hall, Ltd, 1883.

\section{Articles}

Goldsmith, Michael. 'Our Place' in New Zealand Culture: How the Museum of New Zealand Constructs Biculturalism.” Ethnologies comparées 6 (2003): <http:// recherche.univ-montp3.fr/cerce/r6/m.g.s.htm>, visited June 262013.

Thompson, Roger C. "Britain, Germany, Australia, and New Zealand in Polynesia." Tides of History: The Pacific Islands in the Twentieth Century, edited by K.R. Howe, Robert Kiste and Brij Lal. Honolulu: University of Hawai'i Press, 1994.

\section{Reports}

Aboriginal Welfare. Initial Conference of Commonwealth and State Aboriginal Authorities. Canberra: Government Printer, 1937.

Aborigines Department of Western Australia. Report for Financial Year Ending 3oth June 1902, 1902.

Australian Ethnic Affairs Council. Australia as a Multicultural Society, 1977. 
Graham, Douglas. "Crown Proposals for the Settlement of Treaty of Waitangi Claims: Summary." Wellington: Office of Treaty Settlements, 1996.

Hunn, J.K. Report on Department of Maori Affairs with Statistical Supplement, 1960.

Select Committee on the Aborigines and the Protectorate. New South Wales Legislative Assembly Votes and Proceedings, 1849.

\section{Acts of Parliament and Court Cases}

Treaty of Waitangi Act, 1975 .

Māori Language Act, 1987.

New Zealand Court of Appeal. New Zealand Māori Council v. Attorney-General, 1987. 